\title{
MODEL PENGHITUNGAN TARIF PREMI ASURANSI SYARIAH DALAM HUBUNGANNYA DENGAN SEGMENTASI PASAR DAN LABA PERUSAHAAN
}

\author{
Ela Patriana \\ UIN Syarif Hidayatullah Jakarta
}

\begin{abstract}
Model Calculation of Islamic Insurance Premium Rates In Connection With Market Segmentation And Profit's Company. The research aims to analyze the model calculations sharia insurance premium rates for savings products and not saving in connection with market segmentation and company profit. The method used in this research is descriptive qualitative. In accordance with the characteristics of the product, for a savings element that has a market segmentation leads to the individual, while that does not have a savings element, it would be appropriate is marketed to a collection or company. Companies with on investment high return using a relatively small debt. High rate of return allowed them to finance the majority of their funding needs with funds generated from internal activities.
\end{abstract}

Keywords: premium rates, market segmentation, profit

\begin{abstract}
Model Penghitungan Tarif Premi Asuransi Syariah Dalam Hubungannya Dengan Segmentasi Pasar dan Laba Perusahaan. Tujuan dari penelitian ini ialah untuk menganalisis model penghitungan tarif premi asuransi pada produk tabungan dan produk non tabungan terhadap segmentasi pasar dan laba perusahaan. Metode yang dipergunakan ialah deskriptif kualitatif. Terkait dengan karakteristik produk untuk produk tabungan lebih cocok diterapkan kepada segmentasi individu, sedangkan produk yang non-tabungan lebih cocok jika dipasarkan kepada kelompok atau perusahaan. Perusahaan yang berinvestasi pada tingkat pengembalian yang tinggi akan menggunakan hutang yang relatif lebih keci. Tingkat pengembalian yang tinggi akan membolehkan mereka untuk membiayai mayoritas pendanaan yang mereka butuhkan dengan dana yang diperoleh dari kegiatan internal.
\end{abstract}

Kata Kunci: tarif premi, segmentasi pasar, laba 


\section{PENDAHULUAN}

Pertumbuhan perusahaan asuransi syariah dalam dekade terakhir cukup pesat, beberapa asuransi non syariah telah membuka unit bisnis khusus syariah, ini menunjukkan bahwa pangsa pasar syariah memiliki potensi yang tidak kecil untuk dikembangkan. Perusahaan asuransi memiliki bagian khusus yang membedakannya dengan perusahaan lain pada umumnya, yakni bagian aktuaria, yang memiliki peranan dalam menentukan besarnya tarif premi yang diberlakukan untuk masing-masing produk yang ditawarkan ke pasar. Peran inilah yang pada akhirnya membutuhkan sejumlah orang yang dengan keahlian khusus dan sangat paham dasar dalam penentuan secara matematis dan statistik sehingga produk yang dihasilkan diharapkan dapat berkompetisi dengan produk sejenis dari perusahaan berbeda.

Asuransi dapat didefinisikan sebagai suatu mekanisme yang memberikan perlindungan pada tertanggung apabila terjadi risiko di masa mendatang. Pihak tertanggung akan mendapatkan ganti rugi sebesar nilai yang diperjanjikan antara penanggung dan tertanggung apabila terjadi kerugian, sementara pihak tertanggung harus membayar sejumlah premi kepada pihak penanggung (Al Arif, 2012).

Asuransi Syariah (Ta'min, Takaful atau Tadhamun) adalah usaha saling melindungi dan tolong menolong diantara sejumlah orang/ pihak melalui investasi dalam bentuk aset dan/ atau tabarru' yang memberikan pola pengembalian untuk menghadapi resiko tertentu melalui akad (perikatan) yang sesuai dengan syariah. Berdasarkan Dewan Syariah Nasional (DSN) dan Majelis Ulama Indonesia (MUI), Asuransi Syariah adalah sebuah lembaga usaha yang saling melindungi dan tolong menolong di antara sejumlah orang melalui investasi dalam bentuk aset dan/atau tabarru' yang memberikan pola pengembalian untuk menghadapi risiko tertentu melalui akad yang sesuai dengan syariah.

Segmentasi pasar dibutuhkan agar produk yang dihasilkan lebih efektif dan efisien, ini berhubungan erat dengan kebijakan dan strategi perusahaan dalam memasarkan produk tersebut, sehingga ada kesinambungan antara produk yang telah dikemas bagus dengan permintaan pasar. Perusahaan 
melakukan bisnis dengan tujuan agar tercapai laba atau profit yang maksimal, apabila perusahaan telah membuata sebuah produk dengan nilai yang bersaing di pasaran, kemudian membuat sebuah strategi pemasaran yang tepat dengan melakukan segmentasi pasar, diharapkan pada akhirnya produk tersebut memberkan sumbangan besar dalam perolehan laba akhir tahun perusahaan asuransi syariah.

Terdapat beberapa rumusan masalah yang akan diangkat dalam penelitian ini. Pertama, bagaimana model penghitungan tarif premi untuk produk saving dan non saving pada perusahaan asuransi syariah. Kedua, bagaimana penentuan segmentasi pasar berdasarkan produk yang ditawarkan khusus untuk perusahaan asuransi syariah. Ketiga, bagaimana keterkaitan antara jenis produk yang ditawarkan untuk segmen pasar tertentu dengan besarnya profit perusahaan asuransi syariah.

Tujuan dari penelitian ini ialah: pertama, menjelaskan model penghitungan tarif premi khusus untuk produk saving dan non saving pada perusahaan asuransi syariah. Kedua, menggambarkan segmentasi pasar yang tepat untuk produk yang ditawarkan perusahaan asuransi syariah. Ketiga, menjelaskan hubungan antara jenis produk asuransi dan segmentasi pasar dengan besarnya profit perusahaan asuransi syariah.

\section{METODE}

Sumber pengumpulan data yang digunakan dalam penelitian ini adalah data primer dan data sekunder. Adapun data sekunder berupa informasi terkait penghitungan premi produk asuransi, segmentasi pasar yang diterapkan untuk produk tertentu dan data laporan keuangan perusahaan asuransi syariah sesuai dengan produk saving dan non saving yang ditawarkan.

Analisa yang digunakan dalam penelitian ini adalah analisa deskriptif kualitatif, mengumpulkan informasi terkait dengan metode penghitungan premi, baik untuk premi pada produk individu atau yang memiliki unsur tabungan maupun produk kumpulan yang tidak menggunakan unsur tabungan. Data yang didapat tersebut dikaitkan dengan pilihan perusahaan dalam memasarkan produk asuransi tersebut dengan tujuan agar keuntungan perusahaan maksimal. 


\section{PEMBAHASAN}

Sebelum kita membahas terkait denga topik utama ini akan dijelaskan terlebih dahulu secara umum produk asuransi. Pada umumnya produk asuransi terbagi menjadi 2 bagian yakni produk dengan unsur tabungan dan produk tanpa unsur tabungan, pembagian ini biasanya mengacu ke manfaat produk dan proteksi yang akan diterima oleh pemegang polis yang bersangkutan. Di bawah ini bagan yang menjelaskan konsep pengelolaan dana dengan unsur tabungan.

Produk dengan Unsur Tabungan. Produk asuransi yang diperuntukkan bagi pemegang polis yang menginginkan dana berkembang sekaligus proteksi asuransi selama masa perjanjian. Berdasarkan mekanisme yang ada, premi yang dibayarkan oleh peserta terbagi menjadi 3 bagian dan salah satunya merupakan rekening peserta yang pada gilirannya akan diinvestasikan dan peserta mendapat bagi hasil. Produk asuransi yang menerapkan unsur tabungan sangat beragam, dan umumnya masuk dalam kelompok kepemilikan polis secara individu, diantaranya: dana investasi, diperuntukkan bagi nasabah yang menginginkan dana dalam beberapa tahun ke depan, besarnya premi disesuaikan dengan kebutuhan pada saat polis jatuh tempo, dan besarnya bagian dana tabungan bagi peserta tergantung lamanya masa perjanjian dan usia pemegang polis, artinya semakin lama masa perjanjian dan semakin tinggi usia pemegang polis maka bagian yang menjadi tabungan peserta akan semakin kecil, dan berlaku juga sebaliknya.

Produk berikutnya disebut dengan dana haji, yang diperuntukkan bagi nasabah yang menginginkan dana untuk keberangkatan ke tanah suci, masa perjanjian antara 2-10 tahun, dengan demikian diharapkan hasil investasi yang optimal bagi pemegang polis, disamping dana tabungan juga akan didapatkan proteksi asuransinya.

Produk yang dimiliki secara individu dengan unsur tabungan lainnya adalah dana pendidikan, program asuransi yang memiliki manfaat bagi pemegang polis berupa tersedianya dana ketika masuk TK, SD, SMP, SMA, Perguruna Tinggi dan selama 4 tahun perkuliahan, dengan demikian pemegang polis dapat merencanakan pendidikan anaknya dengan lebih terencana dan terprogram, adapun besarnya premi akan disesuaikan dengan 
besarnya kebutuhan pemegang polis. Produk asuransi dana pendidikan adalah suatu bentuk perlindungan untuk perorangan yang bermaksud menyediakan dana pendidikan, dalam mata uang Rupiah dan US Dollar untuk putraputrinya sampai sarjana.

Produk asuransi semakin berkembang dalam beberapa tahun terakhir, disesuaikan dengan kebutuhan masyarakat modern yang menginginkan tercovernya diri dan keluarga, beberapa produk tersebut antara lain, program kesehatan yang awalnya merupakan produk kumpulan, dapat dimiliki masyarakat secara individu juga, program kecelakaan diri yang merupakan tambahan manfaat bagi peserta yang mengambil program utama lainnya.

Semakin maju sebuah negara maka kebutuhan asuransi akan terus tinggi, dengan demikian perusahaan asuransi dituntut untuk lebih professional dalam menjalankan amanah mengelolah dana nasabah tidak menutup kemungkinan juga persaingan bisnis memaksa perusahaan menyesuaikan program yang ditawarkan dengan kebutuhan masyarakat, yang akhirnya akan memberikan dampak beragamnya pilihan program asuransi bagi calon pemegang polis dan dengan demikian akan berpengaruh ke besarnya premi yang menjadi kewajiban pemegang polis, konsumen akan lebih diuntungkan.

Salah satu contoh yang akan dijelaskan adalah, dana investasi dengan premi tahunan sebesar Rp 20.000.000, masa perjanjian 5 tahun, tabarru 3\%, loading 7\%, nisbah bagihasil $60 \%$ peserta dan 40\% perusahaan asuransi, dengan asumsi tingkat investasi 10\% per tahun, dapat dilakukan perhitungan seperti tercantum dalam simulasi berikut. Pada tahun tahun pertama, dari premi Rp 20.000.000, dialokasikan 3\% atau sebesar Rp 600.000 sebagai dana tabarru, dan 35\% atau sebesar Rp 7.000.000 sebagai biaya loading dan hanya dikenakan pada tahun pertama saja, sehingga dana yang dapat dialokasikan menjadi tabungan peserta sebesar $\mathrm{Rp}$ 12.400.000. setelah diinvestasikan selama setahun dengan asumsi tingkat investasi 10\% didapat dana sebesar Rp 744.000 dengan pembagian 60\% peserta dan 40\% perusahaan asuransi. Dana kematian sebesar Rp 100.000.000 yakni dari 5 tahun x Rp 20.000.000 premi tahunan, perhitungan untuk besarnya nilai tunai pada tahun pertama 
merupakan penjumlahan antara tabungan peserta dan bagihasil selama setahun yakni sebesar Rp 13.144.000, adapun besarnya dana klaim meninggal peserta tahun tersebut adalah Rp 113.144.000. Tahun kedua, dari premi yang dibayarkan dan hasil investasi yang diperoleh, maka manfaat nilai tunai menjadi Rp 34.496.640 sedangkan manfaat klaim meninggal Rp 114.496.640, besarnya dana yang dicadangkan sesuai dengan besarnya premi yang telah dibayarkan. Tahun ketiga sampai dengan tahun kelima,berlaku perhitungan yang sama, walaupun dalam perhitungan sebenarnya bisa berbeda tergantung tingkat investasi yang terjadi dalam kurun waktu bersangkutan

Bagi program asuransi tanpa unsur tabungan, pemegang polis hanya akan menerima manfaat proteksi sebesar yang disepakati di awal perjanjian, namun pada akhir masa perjanjian apabila tidak terjadi klaim, maka perusahaan asuransi akan memberikan surplus bagihasil yang besarnya tergantung banyaknya klaim yang terjadi selama kurun masa perjanjian bagi seluruh pemegang polis dengan produk yang sama, konsep yang digunakan adalah saling menolong antara satu pemegang polis dengan seluruh peserta asuransi untuk saling mencakup apabila terjadi musibah.

Produk tanpa unsur tabungan umumnya diperuntukkan bagi peserta asuransi kumpulan, dengan minimal peserta sebanyak 30 orang, terdapat beberapa perbedaan produk dengan unsure tabungan terutama pada alokasi dana yang dibayarkan dan konsep bagihasil untuk perusahaan dan bagian peserta. Berdasarkan mekanisme yang ada, terdapat aliran dana dari premi yang dibayarkan oleh peserta, diinvestasikan dan terdapat bagihasil, tidak terdapat rekening khusus bagi peserta karena tidak menggunakan konsep tabungan. Beberapa produk asuransi yang dimiliki secara kumpulan yakni, program asuransi kecelakaan diri, program ini umumnya bagi perusahaan yang menginginkan jaminan bagi karyawan, atau sekolah untuk para siswanya, perguruan tinggi bagi mahasiswanya, dengan premi yang relatif murah, pemegang polis akan dapat memberikan jaminan perlindungan bagi anggotanya.

Program kesehatan, umumnya bagi perusahaan yang menginginkan anggotanya mendapat perlindungan untuk masalah kesehatan, dengan 2 sistem 
yang diterapkan yakni dengan kartu sehingga peserta tidak membayar biaya perawatan di rumah sakit yang sudah bekerjasama dengan pihak asuransi, atau dengan reimbursement, yakni membayar biaya rumah sakit terlebih dahulu kemudian dapat mengajukan klaim setelah keluar dari rumah sakit disesuaikan dengan besarnya manfaat yang diambil peserta. Selain biaya perawatan terdapat tambahan manfaat yang disesuaikan dengan kebutuhan peserta asuransi, antara lain biaya rawat jalan, penggantian kaca mata, klinik perawatan gigi, biaya persalinan, dll.

Program pembiayaan, bekerjasama dengan pihak perbankan. Jaminan yang diberikan oleh perusahaan asuransi adalah mencover sisa pinjaman peserta, klaim dilakukan dan dibayarkan oleh pihak asuransi ke perbankan, dalam hal ini peserta asuransi akan mendapatkan ketenangan apabila terjadi musibah kematian sehingga keluarga yang ditinggalkan tidak dibebani dengan kewajiban melunasi sisa pinjaman yang bersangkutan.

Beberapa faktor yang mempengaruhi antara lain : mortality table (tabel mortalitas), interest/diskonto dan expenses/biaya. Tabel Mortalitas, merupakan tabel yang menggambarkan tingkat kematian berdasarkan usia dan lamanya masa perjanjian asuransi. Akan sangat berbeda antara negara maju dan negara berkembang, semakin tinggi harapan hidup maka semakin kecil tingkat kematian berarti semakin murah premi yang dibayarkan, begitu juga sebaliknya premi akan semakin tinggi apabila usia harapan hidup rendah.

Kaidah dasarnya memprediksi kapan seseorang akan meninggal tidak mungkin, namun memprediksi jumlah orang yang akan meninggal dalam jangka waktu tertentu msih mungkin dengan menggunakan data statistik, semakin besar jumlah orang yang akan diprediksi maka angka yang didapat akan mendekati nilai sebenarnya, atau hukum bilangan besar.

Berdasarkan data dapat dilihat hubungan antara umur dengan tingkat mortalita seseorang, grafik tinggi pada umur 0 tahun dan semakin menurun sampai dengan umur 5 tahun, kemudian cenderung stabil sampai dengan umur 15 tahun s.d 35 tahun dan perlahan meningkat terutama di atas umut 50 tahun, terdapat perbedaaan antar pria dan wanita, grafik pada pria cenderung lebih tinggi dibandingkan pada wanita, karena usia harapan hidup wanita lebih tinggi, 
disamping faktor domestik, faktor keamanan dan kecenderungan berada di luar rumah menjadi faktor yang menentukan tingginya tingkat kematian pria dibandingkan wanita.

Tabel mortalita tidak dibentuk dari sensus penduduk tetapi dibuat dari pemegang polis asuransi sehingga data yang diperoleh berdasarkan penduduk yang benar-benar layak masuk asuransi, karena tingkat kematian hasil sensus lebih besar dibandingkan tingkat kematian peserta asuransi. Berdasarkan tabel di atas terlihat peluang meninggal akan semakin besar seiring dengan pertambahan usia. Berikut ini dijelaskan mengenai penghitungan premi berdasarkan tabel mortalitas dengan mengabaikan unsur lain. Simulasi yang ada menunjukkan angka dalam per mil atau per seribu, semakin bertambah usia maka peluang kematian semakin meningkat. Apabila kita menghitung berapa peluang seseorang yang berusia 35 tahun meninggal sebelum berusia 36 tahun. Maka dihitung dengan cara sebagai berikut :

$$
\begin{aligned}
\mathrm{q} 35 & =(135-136) / 135 \\
& =\mathrm{d} 35 / 135 \\
& =1.612 / 982.664 \\
& =0.00164 \\
& =1.64 \text { per mil atau per seribu }
\end{aligned}
$$

Artinya adalah bahwa dari 1000 orang yang berusia 35 tahun akan meninggal sebelum berusia 36 tahun sebanyak 1.64 orang, dari 10.000 orang yang berusia 35 tahun akan meninggal sebelum berusia 36 tahun sebanyak 16.4 orang dan dari 100.000 orang yang berusia 35 tahun akan meninggal sebelum berusia 36 tahun sebanyak 164 orang.

Penghitungan premi berikutnya apabila peserta menginginkan ahli waris mendapatkan santunan sebesar Rp 10.000 .000 per orang apabila terjadi musibah meninggal dunia maka berapa iuran per orang, jika rata-rata usia masuk 35 tahun. Berdasarkan tabel di atas diketahui untuk setiap 100 ribu orang jumlah yang diprediksi meninggal sebanyak 164 orang, jumlah uang pertanggungan yang dibutuhkan $\mathrm{Rp} 10.000 .000 \mathrm{x} 164$ orang $=\mathrm{Rp}$ 1.640.000.000, sehingga iuran masing-masing peserta adalah $=\mathrm{Rp}$ 1.640.000.000 / 100.000 orang = Rp 16.400 per tahun. 
Contoh berikutnya apabila usia peserta rata-rata 40 tahun, ahli waris akan mendapatkan dana santunan sebesar 100.000 .000 per orang, maka berdasarkan tabel di atas diketahui untuk setiap 100 ribu orang jumlah yang diprediksi meninggal sebanyak 227 orang, jumlah uang pertanggungan yang dibutuhkan Rp 100.000.000 x 227 orang $=$ Rp 22.700.000.000, sehingga iuran masing-masing peserta adalah $=R p 22.700 .000 .000 / 100.000$ orang $=R p$ 227.000 per tahun.

Perhitungan di atas berdasarkan tabel mortalitas saja, apabila ditambahkan perhitungan interest/diskonto, maka perhitungan akan berubah menjadi : iuran peserta apabila masing-masing ahli waris menerima santunan sebesar Rp 10.000.000, usia rata-rata 35 tahun dengan asumsi investasi 5\% per tahun.

Jumlah prediksi orang meninggal = 164 (asumsi di akhir tahun), jumlah uang pertanggungan yang dibutuhkan $=\mathrm{Rp} 10.000 .000 \times 164$ orang $=\mathrm{Rp}$ 1.640.000.000. diskonto 10 juta di awal tahun $=R p 1.640 .000 .000 /(1+5 \%)=R p$ 1.561 .905 .iuran masing-masing peserta $=\mathrm{Rp} 1.561 .905 / 100.000$ orang $=\mathrm{Rp}$ 15.619 per orang, jika dibandingkan dengan perhitungan hanya menggunakan tabel mortalita saja, terdapat perbedaan sebesar Rp 781 lebih rendah.

Perhitungan kasus kedua, apabila diasumsikan investasi sebesar 5\% per tahun, dengan usia rata-rata 40 tahun, terdapat angka 227 orang yang diprediksi meninggal, maka perhitungan menjadi : Rp 100.000.000 x 227 orang $=\operatorname{Rp} 22.700 .000 .000$. diskonto 10 juta di awal tahun = Rp 22.700.000.000/ $(1+5 \%)=\operatorname{Rp} 21.619 .050 .000$. iuran masing-masing peserta $=R p$ 21.619.050.000 / 100.000 orang = Rp 216.195 per orang, jika dibandingkan dengan perhitungan hanya menggunakan tabel mortalita saja, terdapat perbedaan sebesar Rp 10.805 lebih rendah.

Apabila ditambahkan satu faktor lain yakni ekspenses/biaya, maka perhitungan menjadi : Jumlah prediksi orang berusia 35 tahun meninggal $=164$ (asumsi di akhir tahun), jumlah uang pertanggungan yang dibutuhkan $=\mathrm{Rp}$ $10.000 .000 \times 164$ orang $=\operatorname{Rp} 1.640 .000 .000$. diskonto 10 juta di awal tahun $=$ $\operatorname{Rp} 1.640 .000 .000 /(1+5 \%)=\operatorname{Rp} 1.561 .904 .762$, biaya loading $20 \%$ menjadi $\mathrm{Rp}$ 
1.561.904.762 $/(1-20 \%)=$ Rp 1.952.380.953 .iuran masing-masing peserta $=$ Rp 1.952.380.953 / 100.000 orang $=$ Rp 19.524 per orang, jika dibandingkan dengan perhitungan hanya menggunakan tabel mortalita dan diskonto, terdapat perbedaan sebesar Rp 3.905 lebih tinggi.

Jumlah prediksi orang berusia 40 tahun meninggal $=227$ (asumsi di akhir tahun), jumlah uang pertanggungan yang dibutuhkan $=\operatorname{Rp} 100.000 .000 \mathrm{x}$ 227 orang $=\operatorname{Rp} 22.700 .000 .000$. diskonto 10 juta di awal tahun $=\mathrm{Rp}$ 22.700.000.000/(1+5\%) = Rp Rp 21.619.050.000, biaya loading 20\% menjadi $\mathrm{Rp} 21.619 .050 .000 /(1-20 \%)=\mathrm{Rp} 27.023 .812 .500$.iuran masing-masing peserta $=\operatorname{Rp} 27.023 .812 .500 / 100.000$ orang $=$ Rp 270.238 per orang, jika dibandingkan dengan perhitungan hanya menggunakan tabel mortalita dan diskonto, terdapat perbedaan sebesar Rp 54.043 lebih tinggi.

Semakin tinggi biaya yang diterapkan ke premi maka premi yang dibebankan ke calon pemegang polis akan semakin tinggi, semakin efisien biaya pengelolaan operasional asuransi, memungkinkan menetapkan premi lebih murah dan premi akan semakin bersaing.

Penentuan pasar target dalam memasarkan sebuah produk akan sangat menentukan profit perusahaan maksimal. Sesuai dengan karakteristik produk, untuk yang memiliki unsur tabungan maka segmentasi pasar mengarah ke individu, sedangkan untuk yang tidak memiliki unsur tabungan, maka akan lebih tepat dipasarkan ke kumpulan atau perusahaan dengan minimal kepesertaan 30 orang.

Menurut Kotler, (2009). Perusahaan tidak dapat berhubungan dengan semua pelanggannya di pasar yang besar, luas, atau beragam. Tetapi mereka dapat membagi pasar seperti itu menjadi kelompok konsumen atau segmen dengan kebutuhan dan keinginan berbeda. Kemudian perusahaan harus mengidentifikasi segmen pasar mana yang dapat dilayaninya dengan efektif. Keputusan ini memerlukan pemahaman mendalam tentang perilaku konsumen dan pemikiran strategis yang seksama. Untuk mengembangkan rencana pemasaran terbaik, manager harus memahami apa yang membuat setiap segmen unik dan berbeda. 
Kotler, Kertajaya, Huan dan liu (2003) menyatakan bahwa segmentasi adalah melihat pasar secara kreatif, segmentasi merupakan seni mengidentifikasi dan memanfaatkan peluang-peluang yang muncul di pasar. Pada saat yang sama segmentasi merupakan ilmu (science) untuk memandang pasar berdasarkan variabel geografis, demografis, psikografis dan perilaku.

Al Arif (2014) mendefinisikan segmentasi memiliki peran penting dalam sebuah perusahaan karena beberapa alasan: pertama, segmentasi memungkin perusahaan untuk lebih fokus dalam mengalokasikan sumber daya. Dengan membagi pasar menjadi segmen-segmen akan memberikan gambaran bagi perusahaan untuk menetapkan segmen mana yang akan dilayani. Selain itu segmentasi memungkin perusahaan mendapatkan gambaran yang lebih jelas mengenai peta kompetisi serta menentukan posisi pasar perusahaan. Kedua, segmentasi merupakan dasar untuk menentukan komponen-komponen strategi. Segmentasi yang disertai dengan pemilihan target market akan memberikan acuan dalam penentuan positioning. Ketiga, segmentasi merupakan faktor kunci untuk mengalahkan pesaing, dengan memandang pasar dari sudut yang unik dan cara yang berbeda dari yang dilakukan pesaing.

Menurut Thompson (2000) segmentasi pasar dimulai dari mengidentifikasi mass market (pemasaran massal). Mass market ini terlalu beragam dan sulit untuk menetapkan target market dengan program pemasaran tunggal, dengan demikian pasar tersebut perlu disegmen menjadi kelompok-kelompok yang homogen. Starting point dari segmentasi adalah mass marketing. Didalam mass marketing program pemasaran dilakukan secara massal seperti distribusi massal, promosi massal dan lainnya atau dengan kata lain satu produk untuk semua. Akan tetapi mass marketing tidak selalu sukses dalam melayani pasarnya karena satu program pemasaran tidak bisa melayani pasar yang heterogen sehingga pelu dilakukan segmentasi, niche marketing (relung pasar) dan pasar individu (Kotler, 2003).

Segmentasi pasar terdiri dari usaha untuk mengidentifikasi sebuah kelompok menjadi sebuah kelompok yang memiliki kesamaan. Segmentasi 
merupakan cara tengah antara mass marketing dengan individu. Dalam segmentasi pasar orang yang berada dalam satu segmen diasumsikan benarbenar memiliki persamaan, padahal tidak ada dua orang yang benar-benar memiliki persamaan dalam suatu hal (Kotler, 2003). Namun demikian segmentasi pasar memiliki beberapa keuntungan dibandingkan mass market antara lain perusahaan dapat menciptakan produk dan layanan yang cocok atau sesuai dengan target market. Perusahaan juga akan lebih mudah dalam menetapkan cancel distribusi dan dalam menetapkan komunikasi pemasaran.

Profitabilitas menunjukkan kemampuan dari modal yang diinvestasikan dalam keseluruhan aktiva untuk menghasilkan keuntungan bagi investor. Sedangkan menurut Sartono (2000), profitabilitas merupakan kemampuan perusahaan memperoleh laba dalam hubungan dengan penjualan, total aktiva, maupun modal sendiri. Dengan demikian bagi investor jangka panjang, akan sangat berkepentingan dengan analisa profitabilitas ini.

Seringkali pengamatan menunjukkan bahwa perusahaan dengan tingkat pengembalian yang tinggi atas investasi menggunakan utang yang relatif kecil. Tingkat pengembalian yang tinggi memungkinkan mereka untuk membiayai sebagian besar kebutuhan pendanaan mereka dengan dana yang dihasilkan dari kegiatan internal.

\section{SIMPULAN}

Model penghitungan tarif premi untuk produk saving dan non saving pada perusahaan asuransi syariah mengikuti ketentuan berdasarkan tabel mortalitas, interest/diskonto dan biaya, perbedaaan ada pada surplus underwriting bagi pemegang polis non saving yang bersifat kumpulan. Segmentasi pasar berdasarkan produk yang ditawarkan khusus untuk perusahaan asuransi syariah, difokuskan pada individu dan kumpulan dengan minimal 30 anggota.

Keterkaitan antara jenis produk yang ditawarkan untuk segmen pasar tertentu dengan besarnya profit perusahaan asuransi syariah, dengan mengcover asuransi kumpulan, bagian nisbah bagihasil lebih besar namun 
premi relatif lebih kecil dibandingkan dengan produk individu dengan premi yang besar. Keuntungan perusahaan didapatkan dari polis aktif individu.

\section{PUSTAKA ACUAN}

Al Arif, M.N.R. 2012. Lembaga Keuangan Syariah: Kajian Teoritis Praktis. Bandung: Pustaka Setia.

Al Arif, M.N.R. 2014. Pemasaran Strategik Pada Asuransi Syariah. Jakarta: Gramata.

Amrin, Abdullah. 2007. Strategi Pemasaran Asuransi Syariah. Jakarta: Grasindo. Anshori, A.G. 2008. Asuransi Syariah di Indonesia. Yogyakarta: UII Press

Anwar, K. 2007. Asuransi Syariah Halal dan Maslahat. Surakarta: Tiga Serangkai Christopher, H. et. al. 2007. Manajemen Pemasaran Jasa. Jakarta: Indeks.

Dewi, G. 2007. Aspek-aspek Hukum dalam Perbankan dan Perasuransian Syariah di Indonesia. Jakarta: Kencana.

Kotler, P. \& K.L. Keller. 2009. Marketing Management, Edisi 13. London: Pearson Prentice Hall.

Kurtz, D. \& L.E. Boone. 2006. Principles of Marketing. London: Thomson Corporation. South Western.

Rochaety, Ety, dkk. 2009. Metodologi Penelitian Bisnis dengan Aplikasi SPSS. Jakarta: Mitra Wacana Media.

Satria, N. 2011. Menjadi Agen Asuransi Dahsyat. Yogyakarta: Klik Publishing.

Siamat, D. 2010. Manajemen Lembaga Keuangan. Jakarta: LPFE Universitas Indonesia.

Santoso, S. 2012. Aplikasi SPSS pada statistic Multivariat. Jakarta: PT. Elex Media Komputindo.

Umar, H. 2010. Riset Pemasaran dan Perilaku Konsumen. Jakarta: Gramedia.

Salim, A. 2007. Asuransi dan Manajemen Risiko. Jakarta: PT RajaGrafindo Persada.

Sudarto, J. 1976. Dasar-dasar Ilmu Pasti Asuransi Jiwa. Jakarta: Bumiputera 1912.

Suma, M.A. 2006. Asuransi Syariah dan Asuransi Konvensional: Teori, Sistem, Aplikasi dan Pemasaran. Jakarta: Kholam Publishing. 
Sumanto, A.E. dkk. 2009. Solusi Berasuransi: Lebih Indah dengan Syariah. Bandung: Salamadani.

Sula, M.S. 2004. Asuransi Syariah (Life and General): Konsep dan Sistem Operasional. Jakarta: Gema Insani Press

Sula, M.S. dan Hermawan Kertajaya. 2006. Syariah Marketing. Jakarta: Mizan. 